\title{
EL CRISTIANISMO, LAS BARRAS BRAVAS Y EL DERECHO INTERNACIONAL PRIVADO
}

\section{José León-Barandiarán Hart}

Abogado y doctor en derecho por la Universidad Nacional Mayor de San Marcos. Decano de la Facultad de Derecho y Ciencias Políticas de la Universidad de Lima.

14 de abril del 527 el emperador de Constantinopla, Justino, hizo coronar como emperador asociado a Justiniano, quien prontamente nombró una comisión de diez hombres para reorganizar el sistema legal, poniendo a la cabeza al jurista Triborniano.

En el año 529 se dio a conocer lo que se llamaría el Codex Justinianus o Código Justiniano, que era un sistema organizado de la legislación, compuesto por 4.652 leyes en doce tomos. A ello siguió una colección de cincuenta tomos de opiniones legales de los juristas romanos de los siglos II y III, que servirian para orientar a los jueces en sus interpretaciones. Así el Codex y las Digest, (pandecta y novell) constituyeron lo que se conocería como el Corpus Juris Civilis.

Justiniano pretendía así establecer una conciliación entre las exigencias prácticas que la vida iba presentando con el modelo, reputado como insuperable, del derecho clásico. Considerado como un gran defensor de la romanidad, trató de reconstruir el imperio de Constantino y en sus compilaciones jurídicas intentó fundir el derecho clásico con el derecho en ese entonces vigente. Así, su recolección fue de leges y de iura. En el Codex compiló las constituciones imperiales, reuniendo el material de las dos grandes compilaciones anteriores, hechas en la época de Diocleciano, el Codex Gregorianus y Hermogenianus, así como la colección oficial publicada por Teodosio II y Valentino II, el Codex 
Theodosianus. En la colección de iura, en las Pandectae y Digestae, se recogieron los textos de la doctrina clásica.

Mientras Justiniano pretendía esta unidad jurídica, el imperio romano de Oriente se hallaba, en aquella época, dividido entre dos creencias religiosas, que de alguna manera representaban, no sólo una separación religiosa, sino una división espacial del imperio; pues de un lado los pueblos que se hallaban en la parte oriental, asiática y Egipto se adherían a la creencia denominada monofisista, y en cambio, del otro lado, los pueblos de los Balcanes y Asia Menor, eran tan católicos como los occidentales.

Según la creencia de Nestoriano, Jesucristo era esencialmente humano, pero poseído por un espíritu divino para llevar a cabo su tarea trascendental. Esta creencia originó una reacción contraria. Los teólogos llamados monofisistas sostenían que Jesucristo tenía una naturaleza absolutamente divina, no era hombre, sino Dios. Esta creencia ya había sido rechazada en el Concilio de Calcedonia en el 451.

En la propia ciudad de Constantinopla era evidente la división religiosa y la tensión entre estas dos creencias, la cual se manifestaba en el principal medio de diversión de la época, las carreras en el hipódromo. En éstas, los católicos se identificaban con el color azul y los monofisistas con el verde.

Justiniano, al igual que su tío Justino, era ferviente católico; por eso, en cuanto llegó al trono de Constantinopla, trató de eliminar en el imperio toda presencia religiosa distinta de la católica. Ello fue una expresión del tiempo que corría, en el cual los grupos católicos, cada vez más poderosos, se tornaban más estrictos con respecto a las posibles desinencias.

La ley I, título I, libro I del Codex disponía lo siguiente:
Cunctos populos quos clementiae $\cdot$ nostrae regit imperium in tali volumus religione versari quam divinum Petrum apostolum tradisse remanis religio usque adhuc $a b$ ipso insinuata declarat...

(Queremos que todos los pueblos que rige el Imperio de nuestra clemencia profesen aquella religión que enseñó a los romanos el divino apóstol Pedro, según declara hasta hoy la propia religión por él mismo predicada).

Así como el Codex tenía como finalidad fortalecer la figura del emperador, en tanto absoluto, y que su palabra fuera ley, también era su propósito señalar que el juez, en su calidad de tal, era un representante del emperador, y, por lo tanto, la máxima autoridad en el Tribunal, debiendo observar la ley. Además, a través del Codex, Justiniano trató de consagrar el catolicismo como la religión imperial, según la ley antes citada, y al emperador como juez del dogma.

En este contexto, es evidente que era la facción azul en el hipódromo la que contaba con la simpatía y el apoyo consiguiente del emperador. Durante una festividad que se realizó en enero del 532, los verdes, opositores a la creencia católica, lanzaron constantes provocaciones contra el emperador quien, al comenzar la vigesimosegunda carrera, los mandó callar a través de un mensajero. Ante esta actitud imperial, exacerbados los ánimos por la discrepancia religiosa y el resentimiento por el apoyo del emperador a la causa de sus rivales católicos, los verdes, que apoyaban la creencia monofisista, salieron a las calles de Constantinopla iniciando lo que se conoció como la insurrección nika, pues utilizaron como su grito emblemático el de "nika", que significa victoria. Los rebeldes destruyeron gran parte de la ciudad, entre la cual estaba el edificio religioso más importante, la Hagia Sofía (Sabiduría Santa), 
y llegaron a coronar como emperador a un sobrino del antiguo emperador Anastasio, quien se sentía con más derecho al trono y los había apoyado constantemente.

Justiniano, ante la gravedad de la situación, que se había tornado en incontrolable a causa de los insurrectos que casi se habían apoderado de Constantinopla, tuvo que llamar a su general Belisario quien acababa de derrotar al inmenso ejército persa en la batalla de Dara. Belisario, luego de una terrible matanza, en la que se dice que hubo más de treinta mil muertos, controló la rebelión de la facción de los verdes y la hizo desaparecer definitivamente.

Los motines habían destruido casi toda Constantinopla, ante lo cual Justiniano contrató a los arquitectos Isidoro de Mileto y Antemio de Tralles para su reconstrucción.

Podemos decir que este hecho es uno de los antecedentes más antiguos $-\mathrm{y}$ también más terrible- del fenómeno de lo que en la actualidad se denomina "las barras bravas" y su violencia.

La ley Cunctos Populos, antes mencionada, no sólo originó la consolidación del catolicismo como religión imperial y la aparición de las barras bravas, sino que casi siete siglos después dio inicio al estudio de lo que hoy llamamos derecho internacional privado.

En 1228, en Bolonia, Acursio se preguntaba si un ciudadano de Bolonia, que es demandado en Módena, debe ser juzgado de acuerdo con la ley de esta última ciudad, de la cual no es ciudadano, para concluir que no era así, por cuanto no se hallaba sometido a ella en tanto que no era súbdito de Módena.

Esa afirmación de Acursio estaba basada en el estudio y la glosa que hizo a la ley Cunctos Populos. Ya que en aquella época toda consideración y análisis jurídico se basaba en el derecho romano, que gozaba de gran autoridad, de él debían deducirse las conclusiones para ser reconocidas. En esos tiempos, en que aún se creía en la subsistencia del imperio romano, los juristas, hombres de su época, se apoyaban en lo que había sido su más grande creación, el derecho romano, el cual consideraban todavía vigente.

En la época de Acursio comenzó la recepción en Occidente de aquel derecho romano de Oriente, que casi había sido desconocido. Como derecho romano pasó a ser parte fundamental del derecho común de aquella época, directamente aplicable en las ciudades sin estatuto, que era como se llamaba la ley propia de la ciudad o ley municipal, y supletorio en aquéllas que sí lo tenían.

Es así que Acursio acude al texto de la ley Cunctos Populos para sostener en su glosa, que si el boloñés contrata en Módena, no debe ser juzgado con el estatuto de Módena, al cual no está sujeto. Con ello establece la posibilidad de la aplicación de una ley distinta a la del foro, enunciado que en 1228 fue realmente innovador y dio origen al estudio que hicieron los posglosadores, llamados también estatutarios, y al desarrollo de la rama del derecho que ahora denominamos derecho internacional privado. 